\title{
CAVE ROCK SURFACE TEMPERATURE EVALUATION USING NON-CONTACT MEASUREMENT METHODS
}

\author{
MERITVE TEMPERATUR JAMSKIH STEN Z BREZSTIČNIMI \\ METODANI
}

\author{
Hana STŘEDOVÁ ${ }^{1,2^{*}}$, Tomáš STŘEDA ${ }^{1,2} \&$ Miroslav VYSOUDIL ${ }^{3}$
}

\begin{abstract}
UDC 551.584.6:772.96(437.3)

Hana Středová, Tomáš Středa \& Miroslav Vysoudil: Cave rock surface temperature evaluation using non-contact measurement methods

The aim of this study was to evaluate the rock surface temperature (RST) regime in Kateřinská Cave in the Moravian Karst (Czech Republic, South Moravia) using nondestructive infrared methods. Air temperature monitoring was also included to quantify the dominant factors affecting the RST. Measurements were taken during the period covering January, 2010 to March, 2012. HOBO air temperature sensors with data loggers were placed in front of the cave entrance, in the entrance corridor and on selected sites in the cave interior. An infrared (IR) thermometer was used to measure the surface temperature of the solid rock. The RST in the cave interior during each season was also recorded by IR camera. The average temperature of the rock surface over the two year period was $6.95^{\circ} \mathrm{C}$. The longterm average of the RST was always 0.01 to $0.79^{\circ} \mathrm{C}$ lower than the air temperature. The dynamics of the RST are most obvious at the entrance corridor to the cave, with temperature variability up to $17.34^{\circ} \mathrm{C}$. The dynamism of both the RST and air temperature decrease as the distance from the entrance increases. The lowest RST variability $\left(1.19^{\circ} \mathrm{C}\right)$ was detected at a distance of 271-280 meters from the entrance. The differences in the maximum RST in the monitored profile were relative small, ranging from 7.30 to $8.70{ }^{\circ} \mathrm{C}$. Minimum temperatures in the cold season showed a significant difference among themselves. Changes in rock surface and air temperatures are dominantly influenced by air exchange with the external environment, although the RST may be locally influenced on a short-term basis by other factors, such as attendance and biota. Temperature heterogeneous zones over space in Kateřinská Cave with no air flow were located by thermal imaging. It is therefore an area where unknown spaces or exterior access can be expected.

Key words: cave microclimate, infrared thermometer, infrared camera, rock temperature; Kateřinská Cave, the Czech Republick.
\end{abstract}

\footnotetext{
${ }^{1}$ Mendel University in Brno, Zemědělská 1, 61300 Brno, Czech Republic, e-mail: hana.stredova@mendelu.cz

${ }^{2}$ Czech Hydrometeorological Institute, Kroftova 43, 61667 Brno, Czech Republic, e-mail: tomas.streda@chmi.cz

${ }^{3}$ Palacký University Olomouc, 17. listopadu 12, 77146 Olomouc, Czech Republic, e-mail: vysoudil@pfnw.upol.cz *corresponding author

Received/Prejeto: 08.10.2013
}

\author{
Izvleček \\ UDK 551.584.6:772.96(437.3) \\ Hana Středová, Tomáš Středa \& Miroslav Vysoudil: Meritve \\ temperatur jamskih sten $z$ brezstičnimi metodani
}

$\mathrm{Z}$ meritvami infrardečega sevanja smo raziskovali temperaturne značilnosti površine jamskih sten $\mathrm{v}$ Kateřinski jami na Moravskem krasu v Republiki Češki. Sočasno smo med januarjem in marcem 2010 merili tudi temperaturo zraka. Pri tem smo temperaturna tipala z zapisovalniki podatkov (HOBO) namestili pred vhod $v$ jamo, $v$ vhodni del jame in na več izbranih mest $\mathrm{v}$ jami. Temperaturo površine jamskih sten smo merili $\mathrm{z}$ infrardečim termometrom in $\mathrm{z}$ infrardečo kamero. Povprečna temperatura površine jamskih sten $\mathrm{v}$ dvoletnem obdobju meritev je bila $6,95^{\circ} \mathrm{C}$. Dolgo-časovno povprečje površine jamskih sten je med $0,01^{\circ} \mathrm{C}$ in $0,8^{\circ} \mathrm{C}$ nižje od povprečja temperature zraka. Temperatura stene se preko leta najbolj spreminja $\mathrm{v}$ vhodnem delu jame, za več kot $17^{\circ} \mathrm{C}$ in pada z oddaljenostjo od vhoda. Najnižja spremenljivost $\left(1,19^{\circ} \mathrm{C}\right)$ temperature kamnite površine smo zabeležili na oddaljenosti med $271 \mathrm{~m}$ in $280 \mathrm{~m}$ od vhoda. Najvišja temperatura površine se na izmerjenem profilu gibljejo v območju med $7,3{ }^{\circ} \mathrm{C}$ in $8,7^{\circ} \mathrm{C}$, medtem ko je minimalnih temperatur vzdolž profila $\mathrm{v}$ hladnem obdobju precej večja. Spremembe temperature zraka in površine sten so pretežno posledica izmenjave zraka z zunanjo atmosfero. $\mathrm{Na}$ temperaturo sten lahko pomembno vplivajo tudi drugi faktorji, kot so prisotnost skupin obiskovalcev in živali (netopirjev). $\mathrm{V}$ jami smo odkrili temperaturno heterogena območja na mestih, kjer ni zaznavnega toka zraka,kar kaže na morebitno prisotnost neznanih jamskih prostorov oz. bližino neznanih vhodov.

Ključne besede: jamska mikroklima, infrardeči termometer, infrardeča kamera, temperatura kamnite površine, Republika Češka. 


\section{INTRODUCTION}

The transport of heat into the cave system and the influence of airflow are usually critical for the temperature regime in a cave (de Freitas \& Littlejohn 1987). The air temperature in the cave is characterized by significantly smaller daily and seasonal amplitudes than the external air temperature (e.g. Šebela \& Turk 2011 and others) and is in equilibrium with the internal temperature of its solid rock and water (Badino 2010). In particular, the rock acts as the regulator and stabilizer of air temperature in the cave (Hebelka et al. 2011). The homeostasis of the internal environment of accessible caves is also influenced by the energy input of electrical equipment and visitors, and there is a risk that the capacity of these external inputs will exceed the cave's capacity to absorb them, causing irreversible damage to this unique environment.

Cave rock surface temperature (RST) regimes have been investigated primarily in connection with the creation of ice and its persistence in ice caves (Turri et al. 2005), with bat hibernation (e.g. Clawson et al. 1980 and others), with the effects of visitors (Carrasco et al. 2002) and with the condensation corrosion of limestone (de Freitas \& Schmekal 2005). Potential climate changes can be identified and quantified according to the long-term trend of cave rock temperature after the elimination of the effects of various radiation shield designs, land cover near meteorological stations, etc.

RST is normally monitored by temperature sensors placed in holes in the rock and connected to a data logger. The depth of the sensor location (for monitoring within the rock) plays an important role in measuring the temperature of the rock massif. Luetscher et al. (2008) quantified the energy balance of the Monlesi Cave system by sensors placed in $0.80 \mathrm{~m}$ long boreholes drilled into the cave rock (with a diameter of $0.04 \mathrm{~m}$ ). Martin et al. (2006) used an external probe placed object in a $0.01 \mathrm{~m}$ hole drilled into the rock substrate. Turri et al. (2005) measured rock temperature in an ice cave by two thermocouples inserted into the rock at depths of $0.10 \mathrm{~m}$ and $0.40 \mathrm{~m}$.

The aim of the study was to evaluate the RST regime in Kateřinská Cave using nondestructive IR methods. The outputs of monitoring contribute to better understanding of the karst formation and to more efficient protection and management of accessible caves, as well as to describe the influence of external climate on cave microclimates, etc. as stated for example by Gabrovšek et al. (2011).

For primary thermal surveying and for identifying sites with different temperature conditions, methods of infrared (IR) camera or IR thermometer temperature measurement are ideal because they do not involve contact and are environmentally friendly with no interior cave destruction. IR camera and IR thermometer were used in the research of cave thermal regimes by Marwin and Thompson (2005), Wynne et al. (2008) and Curtis and Kyle (2011). Clawson et al. (1980) used IR thermometers for monitoring ceiling rock and bat cluster temperatures in a cave environment. Boyles et al. (2007), Boyles et al. (2008), Sun-Sook et al. (2009) used IR cameras and thermometers for the interior monitoring of caves with hibernating bats. In karst areas outside the cave environment, airborne thermography was used to locate submerged springs, caves, crevasses, sinkholes, etc. (e.g. Campbell et al. 1996; Rinker 1975 and others).

Although IR thermometry is currently used in a wide range of mostly technical activities (building energy audits, medical applications, fire detection, night vision optics, etc.), its use in monitoring cave temperatures is relatively rare. Recently, the infrared thermography to studying cave interior microclimate used for instance Berenguer-Sempere et al. (2014) or Pflitsch et al. (2012). In particular, continuous monitoring of the surface temperature of the rock surface in a cave environment is unique.

\section{DATA AND METHODS}

\section{STUDY AREA}

The cave environment temperature regime was monitored in the Moravian Karst in Kateřinská Cave (the Czech Republic, South Moravia). According to the climate assessment of the Moravian Karst by Rožnovský et al. (2010a), the long-term average air temperature during the period 1961-2008 was $8.4^{\circ} \mathrm{C}$ and the annual precipitation total was $600 \mathrm{~mm}$. The warmest month is July, with an average temperature of $18.3^{\circ} \mathrm{C}$, and the coldest is January, with an average temperature of $-2.2^{\circ} \mathrm{C}$.

The cave system consists of corridors and three spacious halls with horizontal orientation trending SW - NE. "Hlavní dóm" hall, with dimensions measuring $96 \times 45 \times 20 \mathrm{~m}$, is the largest underground space acces- 
sible to the public in the Czech Republic. "Dóm chaosu" and "Dóm Bambusového lesíku" halls were discovered in 1909, after the discovery of the so-called "Nová Kateřinská" Cave. In the cave, there is no water course or reservoir exerting a strong effect on the microclimate. "Dóm chaosu" hall is vertically connected with an upper floor of the cave "Dantovo peklo". Individual segments of the cave are shown and described in Fig 1 . The total length of all known passages reaches $950 \mathrm{~m}$ with denivelation of more than $50 \mathrm{~m}$. The spacious cave en- to the entrance of the "Hlavní dóm" hall. The transitional climate zone includes the remaining cave spaces, except for the blind side corridors. The corridors lying away from the chimney-effect influence are included in the climatically static zone (Hebelka et al. 2007). Air movement in Kateřinská Cave depends on external temperature changes. External temperatures above approximately $5{ }^{\circ} \mathrm{C}$ causes a reversal of air-flow direction, which is typical for a climatically dynamic cave (Piasecki \& Sawiński 2007).

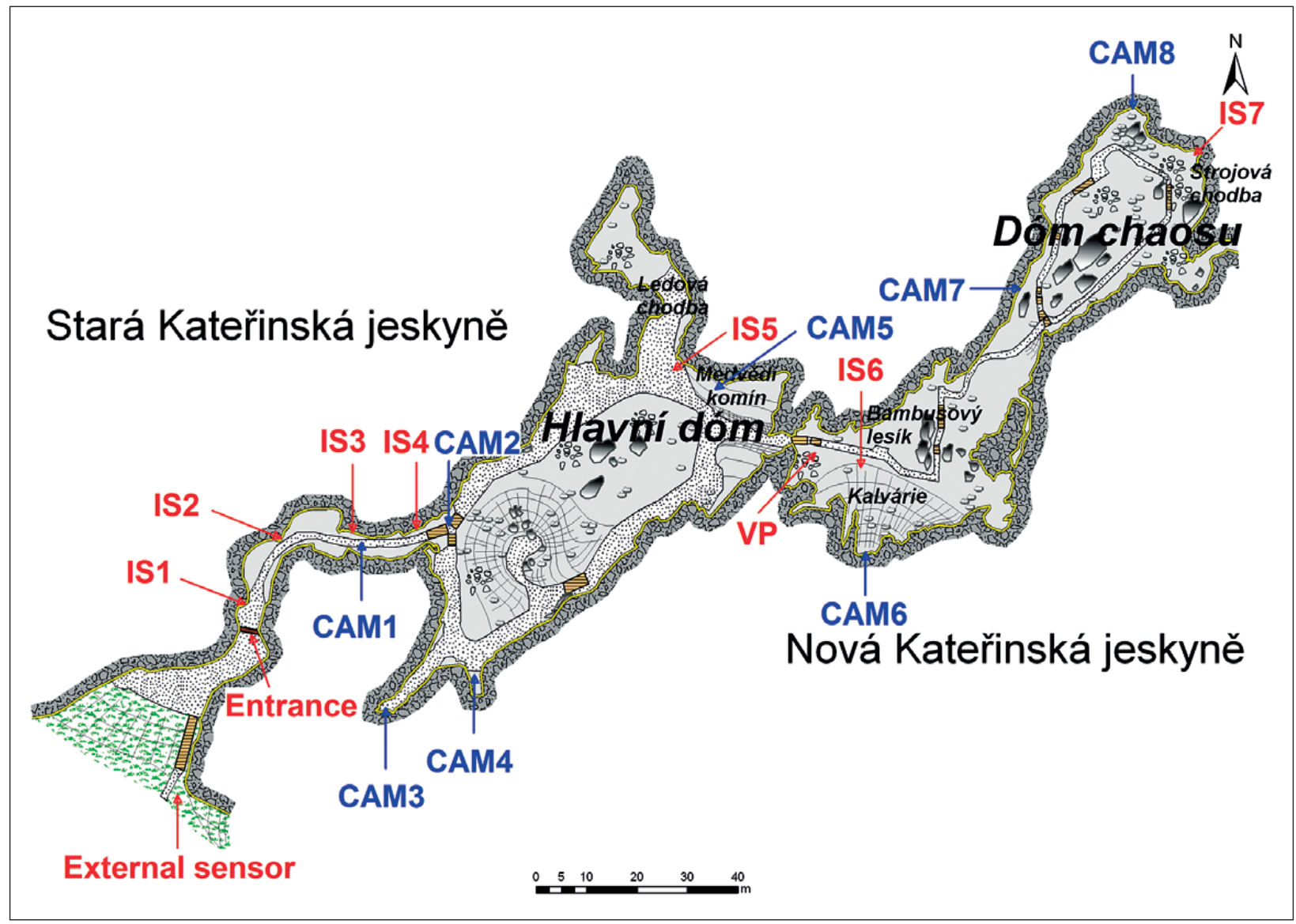

Fig. 1: Location of air temperature sensors (red dots IS1 - IS7 and VP) and the position of the thermal capture records (blue points CAM1 - CAM8).

trance is located approximately $10 \mathrm{~m}$ above the bottom of the "Pustý žleb" gorge, which is approximately $100 \mathrm{~m}$ deep. The cave entrance is closed by a door with a hole for migrating bats. Annual attendance in Kateřinská Cave varies between 30 to 50 thousand visitors (up to 900 visitors in one day, maximum of 60 persons per group). The cave is closed to visitors from December to the end of February.

Three main climate zones occur in the cave. The dynamic climate zone extends from the cave entrance

\section{AIR TEMPERATURE MEASUREMENT}

Air temperature at a height of $1 \mathrm{~m}$ was measured in representative areas, i.e., the entrance corridor (IS1 - IS4 sensors) and the deep main cave parts (sensors IS5 - IS7 and vertical profile VP) - Fig. 1. Those areas and the external environment (measured with an external sensor in front of the cave entrance) were monitored by the U23 HOBO Pro V2 with a data logger, an accurate air temperature sensor. The accuracy of the HOBO U23 V2 is $\pm 0.21{ }^{\circ} \mathrm{C}$, with a resolution of $0.02{ }^{\circ} \mathrm{C}$. It took one minute 
for the interior sensor to capture air temperature differences caused by human attendance and other visitors. External sensors and interior control sensors measured at 15 minute intervals, and the fifteen minute averages were used for the air temperature evaluation.

\section{RST MEASUREMENT (IR THERMOMETER)}

The surface temperature of the rock was measured with the Raytek MX4 Raynger MX4 ${ }^{\mathrm{TM}}$ IR thermometer. The sensor measures the amount of long wave radiation emitted from the monitored surface based on the Stefan - Boltzmann law and shows the surface temperature of the monitored subject. The amount of emitted radiation varies according to the physical and chemical properties of the surface. The recommended value for limestone emissivity, $\varepsilon=0.98$ (Thermemether's manual - Raytek 1999), was used. The sensor measures the surface temperature with a resolution of $0.1{ }^{\circ} \mathrm{C}$ and an accuracy of $1.0^{\circ} \mathrm{C}$. Monitoring was conducted at semi-monthly to monthly intervals. The interval is fully sufficient because of the limited annual dynamism of the RST. The RST was measured along the tour route and blind corridor in the southwest part of the cave at $0.03 \mathrm{sec}$ intervals at a height of $1.50 \mathrm{~m}$ above the ground. The constant speed of the sensor movement was controlled by the BOSS DB-60 digital metronome.

\section{RST MEASUREMENT (IR CAMERA)}

In addition to point measurements, the cave surface temperature for each season was also monitored by the Fluke Ti55 IR fusion technology IR camera with a thermal sensitivity $\leq 0.05^{\circ} \mathrm{C}$. The size of the images taken was $320 \times 240$ pixels. The actual size of the monitored area and the spatial resolution depends on the distance from the target. In our case, the target distance did not exceed $20 \mathrm{~m}$, indicating that the size of the monitored area is $8 \times 6 \mathrm{~m}$. Other technical parameters of the device are given in Fluke (2007). The Technology IR - Fusion allows simultaneous recording of both the IR and the visible spectrum.

The position of monitored points (CAM1-CAM8) is given in Fig. 1. Point CAM1 is located in the northern wall of the entrance corridor at a height of 0-2 m. CAM2 shows the RST of "Hlavní dóm" hall ceiling at a height of $20 \mathrm{~m}$. CAM3 was placed in a vertical chimney in a blind corridor in "Hlavní dóm" hall. CAM4 is located in the horizontal projection and depressions in the southeastern part of "Hlavní dóm" hall. CAM5 shows the RST of the "Medvědí komín" chimney in the northeastern part of "Hlavní dóm" hall. CAM6 is located in "Dóm Bambusového lesíku" hall and above the debris field called "Kalvárie". CAM7 shows the RST in a vertical chimney leading to the upper levels of the cave in the southwestern part of "Dóm chaosu" hall. CAM8 is located the north vertical walls in "Dóm chaosu" hall at a height of $8 \mathrm{~m}$.

\section{DATA EVALUATION}

The results that we evaluated represent the period from January 2010 to March 2012, i.e., three cold and two hot seasons. The evaluation and statistical expression of the data were generated by the STATISTICA software (StatSoft, ver. 7) - Fig 2. This software was also applied to evaluate the dependence of internal temperature on the external temperature and its delay for a specific location in a cave (cross correlation method). The data from the IR thermometer measurement was interpolated by the kriging method in SURFER software (Golden Software, ver. 8.03) - Fig. 3 and 4. The course of the RST during different seasons is dependent on the distance from the entrance and was subsequently expressed in $2 \mathrm{D}$ projection. Thermal images from the IR camera were processed by the SmartView 3.1.89.0 software, Fluke Thermography - Fig. 5 to 11 .

\section{RESULTS AND DISCUSSION}

\section{IR THERMOMETER MEASUREMENT}

The results of RST monitoring are presented in Fig. 2. The RST along the return (southeastern) route of the guided tour was evaluated. The average statistical indicators of rock temperature in $10 \mathrm{~m}$ sections were processed for the entire period, and the two-year rock temperature average was $6.95^{\circ} \mathrm{C}$. Significant dynamics of surface temperature presented in the entrance area, with temperature variability up to $17.34^{\circ} \mathrm{C}$; this dynamism decreases with increasing distance from the entrance. Stronger temperature variability in the cave rear caused by lower minimum temperatures occurred only at the interface of "Stará Kateřinská jeskyně" and "Nová Kateřinská jeskyně" and in the "Kalvárie" area, 161-190 $\mathrm{m}$ from the entrance.

Average RST increased significantly $110 \mathrm{~m}$ from the entrance. Differences in the maximum RSTs $\left(7.30-8.70{ }^{\circ} \mathrm{C}\right)$ in the monitored profile are relatively small. Significant differences in minimum temperatures for the monitored temperature profile were gener- 


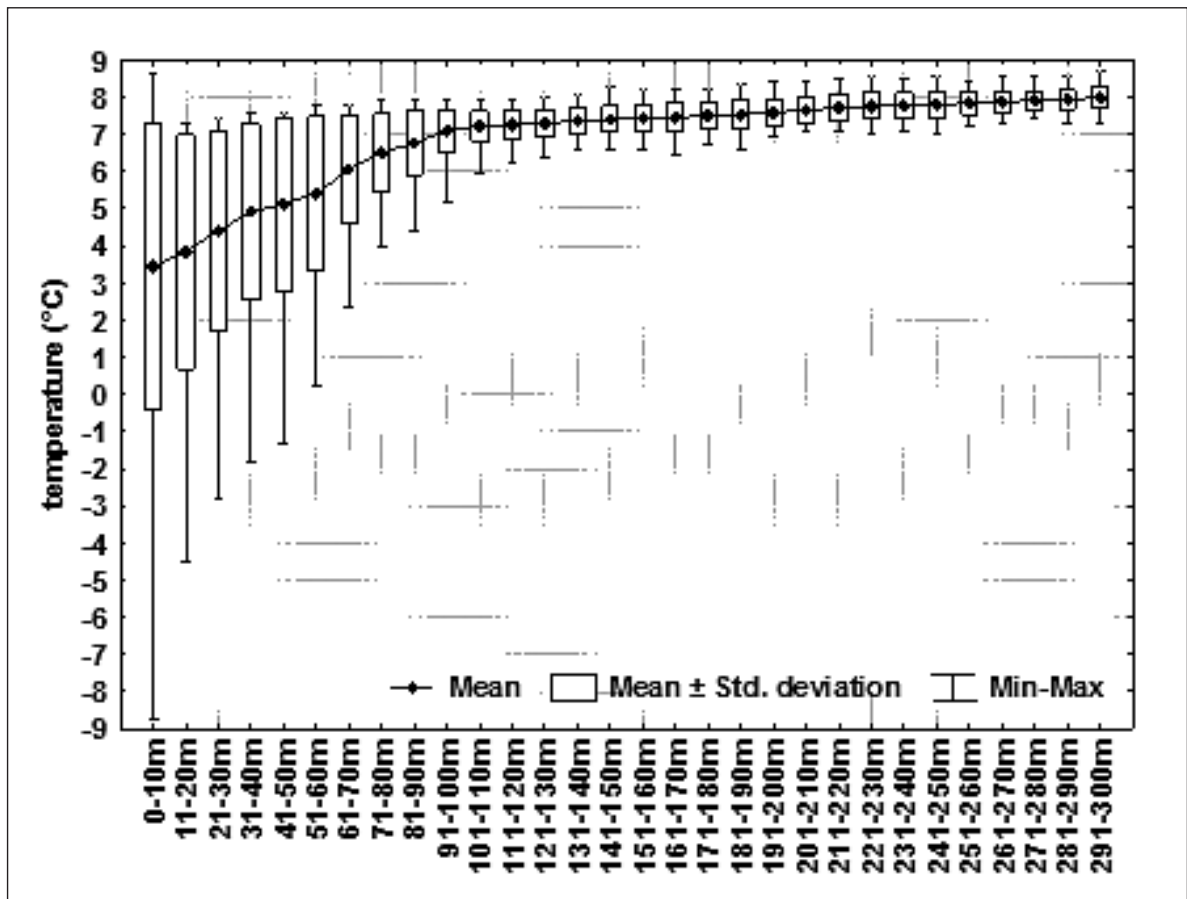

Fig. 2: Basic statistical characteristics of RST in $10 \mathrm{~m}$ section from the cave entrance.

ated during the cold months. During the winter, cold air flows through the cave; the cave undergoes changes in temperature and relative humidity as a result of the heat transferred to and from the cave walls (Luetscher et al. 2008).

The lowest measured RST in Kateřinská Cave during this period was $-8.75^{\circ} \mathrm{C}$, and the highest was $8.70{ }^{\circ} \mathrm{C}$. The smallest variability of RSTs $\left(1.19^{\circ} \mathrm{C}\right)$ was found $271-280 \mathrm{~m}$ from the entrance. For neighboring "Punkevní jeskyně" during the period from 2007 to 2011, Hebelka et al. (2011) reported an average rock temperature of $8.21^{\circ} \mathrm{C}$, a maximum temperature of $8.49^{\circ} \mathrm{C}$ and a minimum temperature of $7.90^{\circ} \mathrm{C}$ (sensors located 0.20 $\mathrm{m}$ in rock massif). Turri et al. (2005) reported seasonal rock temperature fluctuation of up to $2{ }^{\circ} \mathrm{C}$; during "cold" events, the rock was affected by the air temperature minimally, at least in the first $0.40 \mathrm{~m}$. Badino (2010) reported daily limestone temperature fluctuations in thicknesses of $0.2 \mathrm{~m}$ and annual fluctuations in thicknesses of 3-4 m. Luetscher et al. (2008) present a temperature gradient in Monlesi Cave between 0.44 and $0.70{ }^{\circ} \mathrm{C} . \mathrm{m}^{-1}$.

The monitoring in Kateřinská Cave showed that changes of air and RST are dominantly influenced by exterior conditions. Rožnovský et al. (2010b) arrived at the identical conclusion while evaluating air temperatures, with possible connection to rock temperatures, in Kateřinská Cave. Air temperatures vary up to $2{ }^{\circ} \mathrm{C}$ in the central part of Kateřinská Cave. Hebelka et al. (2011) employed a method of cross correlation which is generally used when measuring information between two different time series. Is it a standard method of estimating the degree to which two series are correlated. An analysis of the closeness of the relationship with the outside temperature using a cross-correlation method was processed using the IS7 air temperature sensor. The most significant statistical correlation between internal and external temperatures was when the outer line was shifted approximately 22 days backwards $(\mathrm{R}=0.822)$. This indicates that Kateřinská Cave has an inertia of internal air temperature of approximately 3 to 5 weeks, and the correlation coefficients ranging from 21 to 35 days are almost identical.

Semi-monthly to monthly measurements of rock temperature by IR thermometers were interpolated and expressed in a $2 \mathrm{D}$ graph (Fig. 3). The RST was stable in the summer months, with a lower value in the entrance area. It is probably caused by the fact the heat conduction from exterior as well as weak outflow of relatively warm air do not outweigh the consequence of winter temperature decline. The RST has a dynamic character in the front part of the cave during the rest of the year. The effects of an energy exchange between the rock massif and the cave atmosphere is clear here. Obleitner \& Spötl (2011) described the seasonal influences on rock temperature at the cave entrance identically in similar climatic condition within the Eisriesenwelt Cave, Austria. Towards the interior of Kateřinská Cave, the influence of external conditions weakens and a delay as to the temperature in cave rear is fairly stable throughout the whole period (see Fig. 3).

The differences between air temperature and RST (rock temperature substracted from air temperature) 


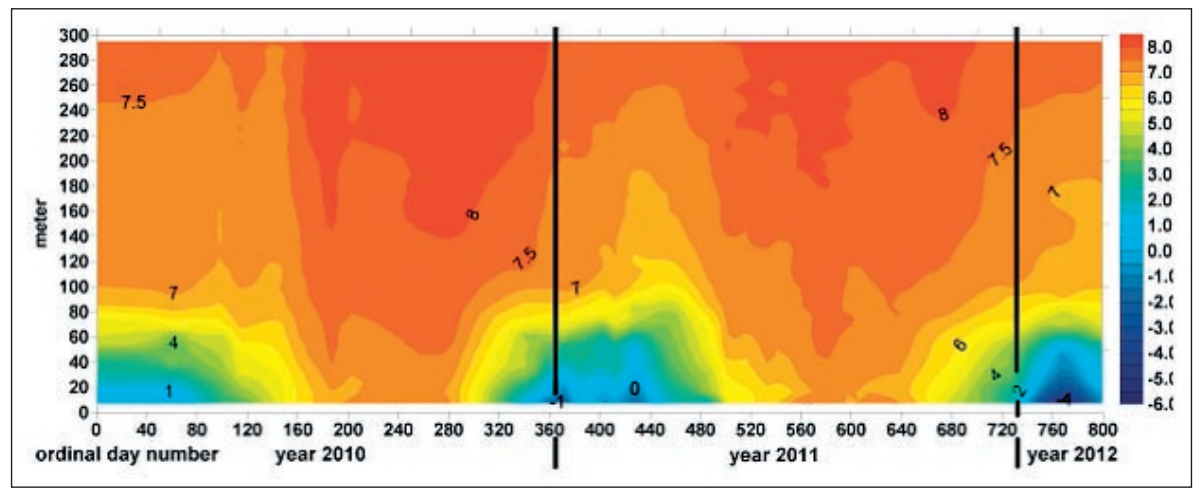

Fig. 3: $R S T\left({ }^{\circ} \mathrm{C}\right)$ in Kateřinská Cave from January 2010 to March 2012.

were calculated, using the time and position in the cave. More significant temperature differences were recorded in winter. Positive temperature differences occur in the winter immediately behind the entrance into the cave. This phenomenon is mainly caused by the freezing of the rock massif by heat conduction and increased by the sudden supply of cold air from the external environment (see Fig. 4 - for instance: $30^{\text {th }}$ to $40^{\text {th }}$ day, $280^{\text {th }}$ to $300^{\text {th }}$ day and 680 to $700^{\text {th }}$ day). The cold air flows into the cave and cools the host rock. The temperature regime of the entrance hall is also affected by the temperature gradient of interior and exterior temperatures, which influences the direction of airflow in the cave. When changing the direction of air flow, the difference between the temperature of incoming autochthonous air and rock temperature shoots up briefly to $6^{\circ} \mathrm{C}$. In summer, warm air flows through the chimneys into the entrance corridor hall, bringing heat to the rock. Air temperature and RST in the summer are identical most of the time.

Behind the dynamic section of the entrance corridor, there is an area that is made up of part of the entrance corridor connected to the "Hlavní dóm" hall and the southeastern part of the "Hlavní dóm" hall; in this area, the air temperature in winter is up to $3{ }^{\circ} \mathrm{C}$ lower over the short-term than the temperatures of the rock surface. Winter subcooling of this section is caused by the inflow of cold air from the entrance corridor. Allochtonous air flows around the cave from the southern side
(Hebelka et al. 2011). Stratification of air temperature and RST in the "Hlavní dóm" hall is significantly influenced by its topography. The influence of the cold air intake from the area near CAM4 (Fig. 11) and its accumulation in the southern part is possible, below "Hlavní dóm" hall. Air temperature and RST in the remaining parts of the cave are basically identical.

The monitoring results of air temperature and the RST differences at sensors IS1 - IS7 are listed in Tab. 1. Long-term averages do not present higher temperatures for the rock surface. Average long-term RST was always lower than the air temperature, with a range of difference from 0.01 to $0.79^{\circ} \mathrm{C}$. These results correspond with the findings of Carrasco et al. (2002) that rock temperature is approximately $1.0^{\circ} \mathrm{C}$ to $2.0^{\circ} \mathrm{C}$ lower than air temperature; they also correspond to the findings of Jeannin (1991) and Luetscher and Jeannin (2004) that rock temperature is close but slightly lower than air temperature (approximately $0.15^{\circ} \mathrm{C}$ ). The RST variability decreases with increasing distance from the entrance. The air flowing and temperature regime of RST and air temperature is also influenced by number of other factors. In individual cases in the differences between air and rock temperature depends for example on whether it is upper or lower entrance, or convection cell. Milanolo a Gabrovsek (2009) described an effect of gravity on seasonal temperature regime of Srednja Bijambarska Cave, Bosnia and Herzegovina. An influence of atmospheric

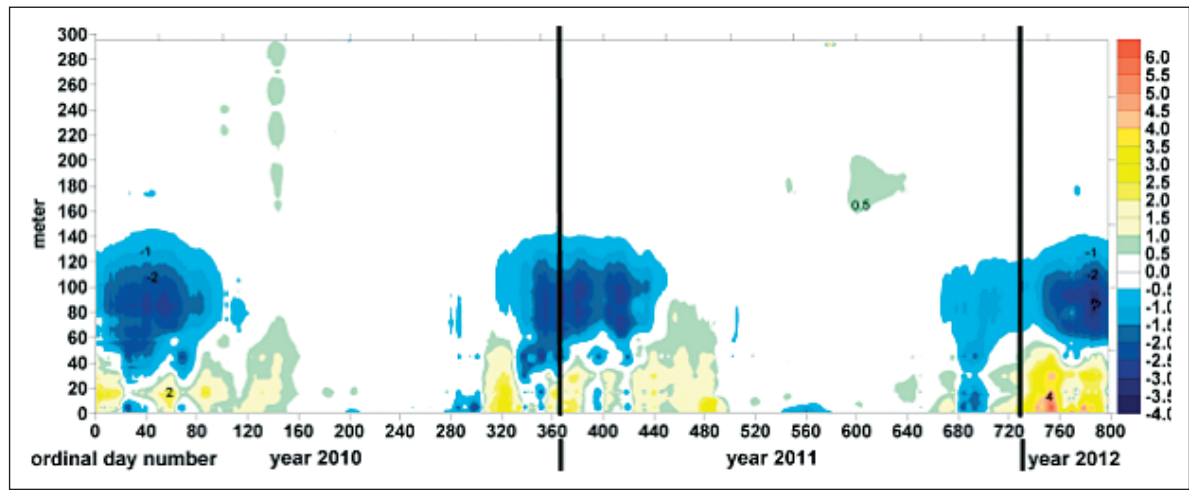

Fig. 4: Difference of air temperature and $R S T\left({ }^{\circ} \mathrm{C}\right)$ from January 2010 to March 2012. 
Tab. 1: Comparison of air temperature and rock surface temperature at measurement points (entire period).

\begin{tabular}{l|c|c|c|c|c|c}
\hline Measurement point & Place & Average & Std. deviation & Minimum & Maximum & Variability \\
\hline \multirow{2}{*}{ IS1 } & Air & 4.03 & 3.13 & -6.34 & 7.69 & 14.03 \\
\cline { 2 - 8 } & Rock & 3.32 & 3.67 & -7.08 & 8.54 & 15.62 \\
\hline \multirow{2}{*}{ IS2 } & Air & 4.61 & 2.57 & -4.55 & 8.23 & 12.78 \\
\cline { 2 - 8 } & Rock & 3.82 & 2.92 & -3.88 & 7.30 & 11.18 \\
\hline \multirow{2}{*}{ IS3 } & Air & 5.21 & 1.96 & -0.50 & 8.07 & 8.57 \\
\cline { 2 - 8 } & Rock & 4.54 & 2.39 & -1.54 & 7.39 & 8.93 \\
\hline \multirow{2}{*}{ IS5 } & Air & 5.13 & 2.41 & -2.51 & 8.23 & 10.74 \\
\cline { 2 - 8 } & Rock & 5.06 & 2.15 & -0.94 & 7.60 & 5.54 \\
\cline { 2 - 8 } & Air & 7.43 & 0.36 & 6.60 & 8.12 & 1.52 \\
\hline \multirow{2}{*}{ IS7 } & Rock & 7.42 & 0.33 & 6.75 & 8.17 & 1.42 \\
\cline { 2 - 8 } & Air & 7.62 & 0.52 & 6.08 & 8.57 & 2.49 \\
\hline
\end{tabular}

pressure gradient is described by Fernandez-Cortes A. et al. (2009).

Anomaly IS4 (lower minimum air temperature than IS3 when temperature tends to decrease with increasing distance from the entrance) results from the leveling of the bottom of the cave and from inverse temperature stratification. The IS4 sensor was affected by the inflow of cold air from outside in winter. Cold air accumulates at the end of the entrance corridor in front of the stairs to the "Hlavní dóm" hall. Lower minimums and higher maximums of air temperature near IS6 (area "Kalvárie") show the influence of the external environment on air temperature. Under the dome ceiling, air flows through the rubble of the unknown parts of the cave system. Air temperature is influenced here by rock thermals and access to the exterior. In the summer, the partial effects of visitors on the maximum air temperature (IS6) remain in place for a long time.

\section{IR CAMERA MEASUREMENT}

During our study, parts of the cave were monitored by IR camera. Monitoring also focused on areas in which the influence of external conditions on the temperature regime was expected. Kermode (1979) attributed 3.6\% of temperature changes to visitors and lighting effects in Waitomo Cave. For this reason, areas with direct and indirect influence of visitors were also monitored (Fig. 5 and 6). The possible influence of factors such as visitors or biota on the RST may be considered to be short-term and significant for local measurements. The large volume of air and its flow in Kateřinská Cave takes away and disperses transferred heat energy radiated by visitors. Carrasco et al. (2002) present the maximum daily fluctuations of rock temperature caused by the influence of visitors at $0.15^{\circ} \mathrm{C}$. Zelinka (2002) recorded and correlated the influence of visitors to the changes in rock and aragonite temperature, with a quick return to average

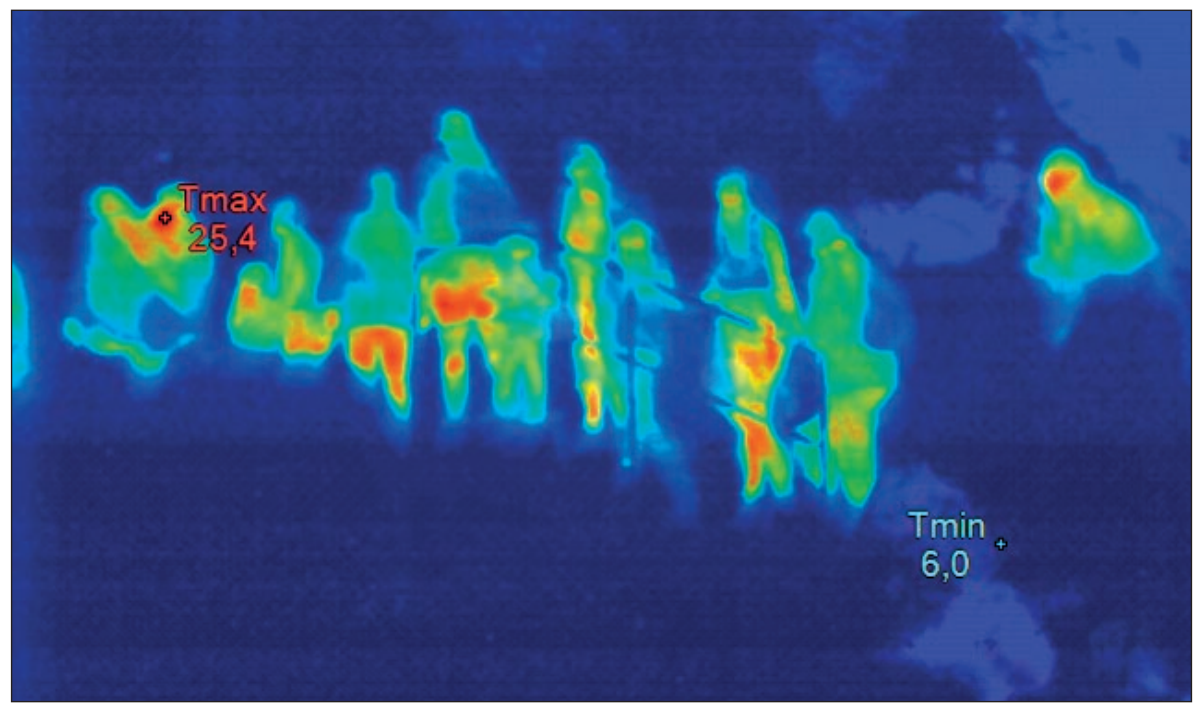

Fig. 5: Anthropogenic input of heat into the cave environment by visitors. 


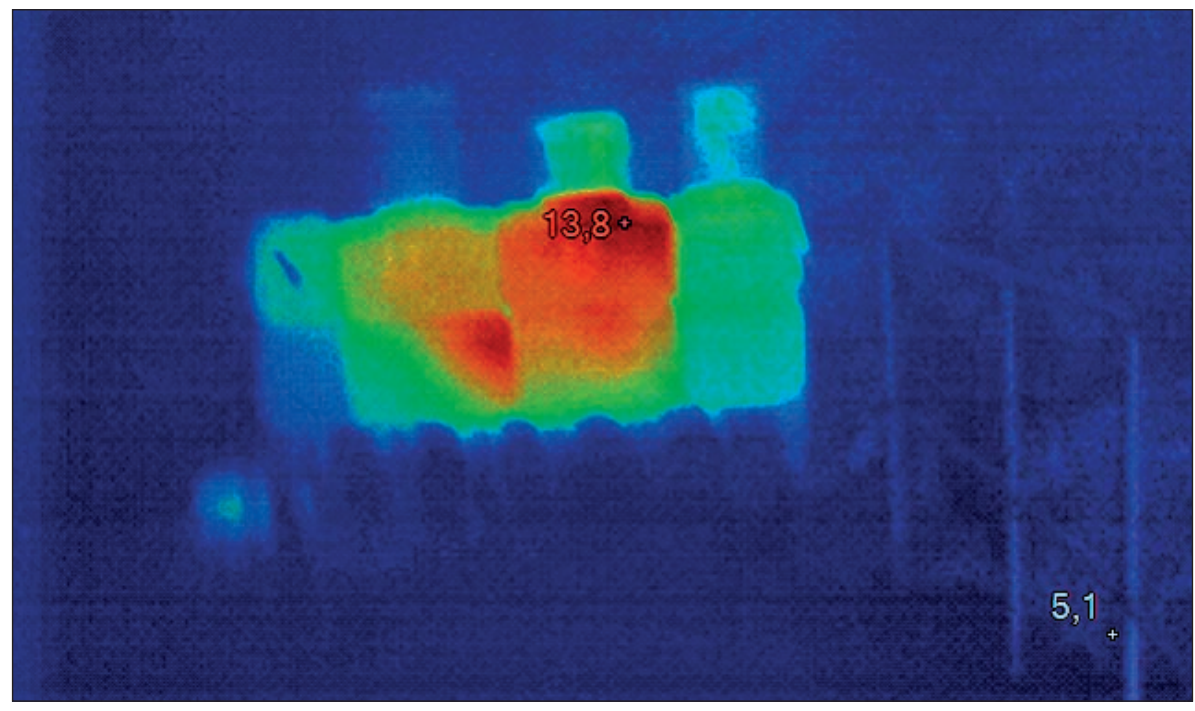

Fig. 6: Anthropogenic input of heat into the cave environment by electrical device.

values. Calaforra et al. (2003) presented a temperature memory effect for visitors of 5-6 hours for cave air. The memory effect on rock temperature in this case is negligible. In caves with bats, the rock temperature is influenced (locally) by bat roosting. Boyles et al. (2008) discovered temperature differences between rock and cluster temperatures of $0.30^{\circ} \mathrm{C}$, using thermal analysis and a cluster of hibernating bats. Lundberg and McFarlane (2009) used the Raytek ST60 IR thermometer to determine that the temperature of "bell holes" with bats is approximately $1.1{ }^{\circ} \mathrm{C}$ higher than those without bats. Rock temperature returns to normal during bat foraging periods after approximately 5 hours.

Temperature minimums and maximums for the individual measuring points during the year are given in Tab. 2. CAM4 monitoring was performed only in February 2011; therefore, it is not evaluated in Tab. 2. Absolute values of RST are approximately $1-2{ }^{\circ} \mathrm{C}$ lower than the values measured by the IR thermometer. The differences are caused by divergent measuring principles, such as point measurement of several square meters versus surface measurement. IR cameras monitor the scene with a size of tens of square meters and a scattering of values that are associated with it. It is also affected by the accuracy of the instruments (IR thermometer $1.0^{\circ} \mathrm{C}$, IR camera $\pm 2{ }^{\circ} \mathrm{C}$ or $2 \%$ ). In addition to this the IR camera required to set a background temperature. In our case was set identically for all measuring points as $7^{\circ} \mathrm{C}$. To assess the development of the RST in time and to compare temperatures of various places during one measurement, the relative expression of temperatures (their difference) is sufficient. In accordance with previous results, the largest RST differences in frame of seasonal imagines were found in the entrance corridor (CAM1) $12.4^{\circ} \mathrm{C}$, in a blind corridor in the southwest part of the cave (CAM3) $5.4{ }^{\circ} \mathrm{C}$ and in the locality "Kalvárie" (CAM6) $9.5^{\circ} \mathrm{C}$ (see Tab. 2). By contrast, the results of CAM2 are influenced by the localization of monitoring (the RST of the ceiling

Tab. 2: Thermal characteristics of the rock surface in each season based on the evaluation of thermal images.

\begin{tabular}{|c|c|c|c|c|c|c|c|c|}
\hline & \multirow[b]{2}{*}{ Date } & \multicolumn{7}{|c|}{ Measurement point } \\
\hline & & CAM1 & CAM2 & CAM3 & CAM5 & CAM6 & CAM7 & CAM8 \\
\hline \multirow{5}{*}{$\begin{array}{l}\text { Minimum } \\
\text { temperature } \\
\left({ }^{\circ} \mathrm{C}\right)\end{array}$} & 28.2 .11 & -2.5 & 4.2 & 3.8 & 4.2 & 1.0 & 5.4 & 6.6 \\
\hline & 3.5.11 & 2.4 & 4.2 & 4.1 & 4.8 & 5.1 & 5.8 & 6.0 \\
\hline & 2.8 .11 & 4.5 & 5.5 & 5.4 & 4.2 & 6.8 & 5.1 & 5.8 \\
\hline & 29.9.11 & 5.1 & 4.8 & 7.3 & 5.9 & 5.9 & 7.1 & 7.5 \\
\hline & 8.2 .12 & -5.9 & 4.3 & 4.2 & 4.3 & -1.5 & 5.0 & 5.0 \\
\hline \multicolumn{2}{|l|}{ Range } & 11.0 & 1.3 & 3.5 & 1.7 & 8.3 & 2.1 & 2.5 \\
\hline \multirow{5}{*}{$\begin{array}{l}\text { Maximum } \\
\text { temperature } \\
\left({ }^{\circ} \mathrm{C}\right)\end{array}$} & 28.2 .11 & -1.5 & 5.6 & 5.4 & 6.0 & 5.6 & 6.5 & 7.9 \\
\hline & 3.5.11 & 4.1 & 5.6 & 5.8 & 6.4 & 6.6 & 7.0 & 7.6 \\
\hline & 2.8 .11 & 6.0 & 7.0 & 7.4 & 6.9 & 8.0 & 6.5 & 7.4 \\
\hline & 29.9.11 & 6.5 & 6.6 & 9.2 & 7.5 & 7.0 & 8.4 & 7.5 \\
\hline & 8.2 .12 & -2.6 & 5.6 & 5.5 & 5.1 & 5.3 & 6.3 & 5.3 \\
\hline \multicolumn{2}{|l|}{ Range } & 8.0 & 1.4 & 3.8 & 2.4 & 2.7 & 2.1 & 2.6 \\
\hline
\end{tabular}




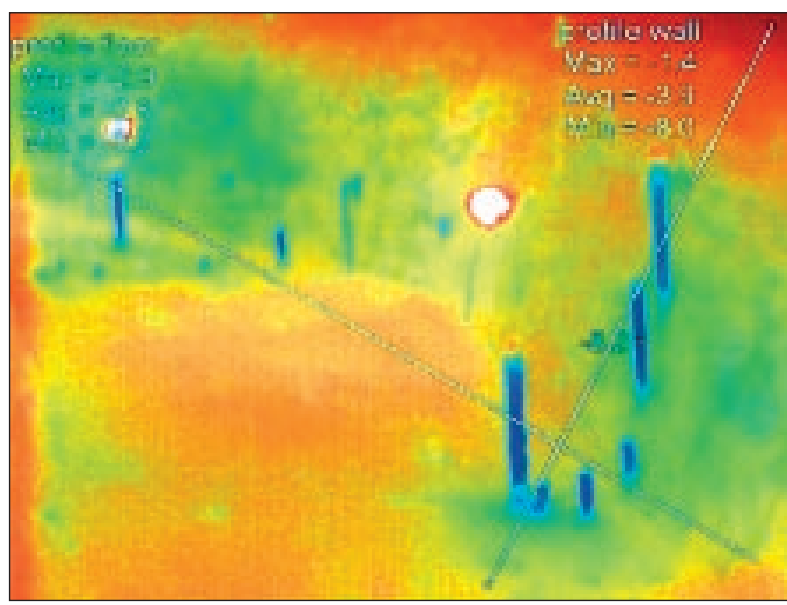

Fig. 7: Thermal image of entrance corridor (CAM1 February 8 2012).

of the cave at a height of $20 \mathrm{~m}$ ). At this height, near the ceiling of "Hlavní dóm" hall, airflow is eliminated due to rugged ceiling morphology and higher temperature compared to floor. The area is also thermally stable.

Chosen thermal images were analyzed in detail and their analyses are shown in Fig. 7 to 11 .

RST inversion (i.e. lower temperature above the floor than under the ceiling) is demonstrated by the IR camera image from the entrance corridor (February 2012) in Fig. 7. Ice stalagmites have been generated in the front part of entrance corridor. They are not formed on a higher level than approximately $1.20 \mathrm{~m}$. In combination with an absence of ice stalactites it proves an assumption of warmer air layer in upper part of the

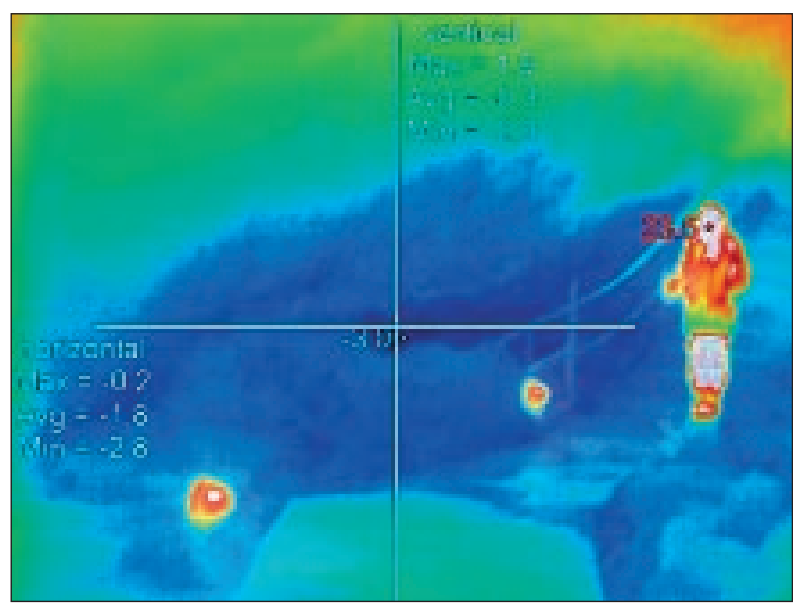

Fig. 8: Penetration of cold air from the entrance corridor to "Hlavní dóm" hall (February 8 2012).

corridor. Warm internal air from remote parts of the cave flows above cool air layer (Hebelka et al. 2011). A layer of warmer air occurs under the cave roof and the cooling of the rock is thus less intense and slower. Additionally, Smithson (1993) recorded significant vertical temperature stratification over the winter. Bourges et al. (2006) found the highest temperature in the central part of the vertical profile of the spacious cave l'Aven d'Orgnac.

The thermal image in Fig. 8 shows the area near sensor IS4 and CAM2 in the winter. At the boundary between the entrance corridor and "Hlavní dóm" hall, cold air and warm air mix. A significantly heterogeneous temperature zone is generated there. In winter rock
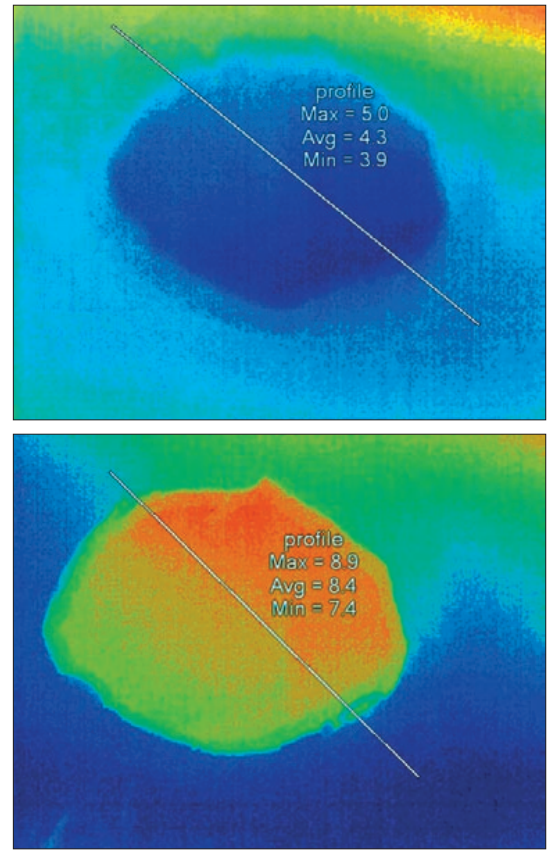
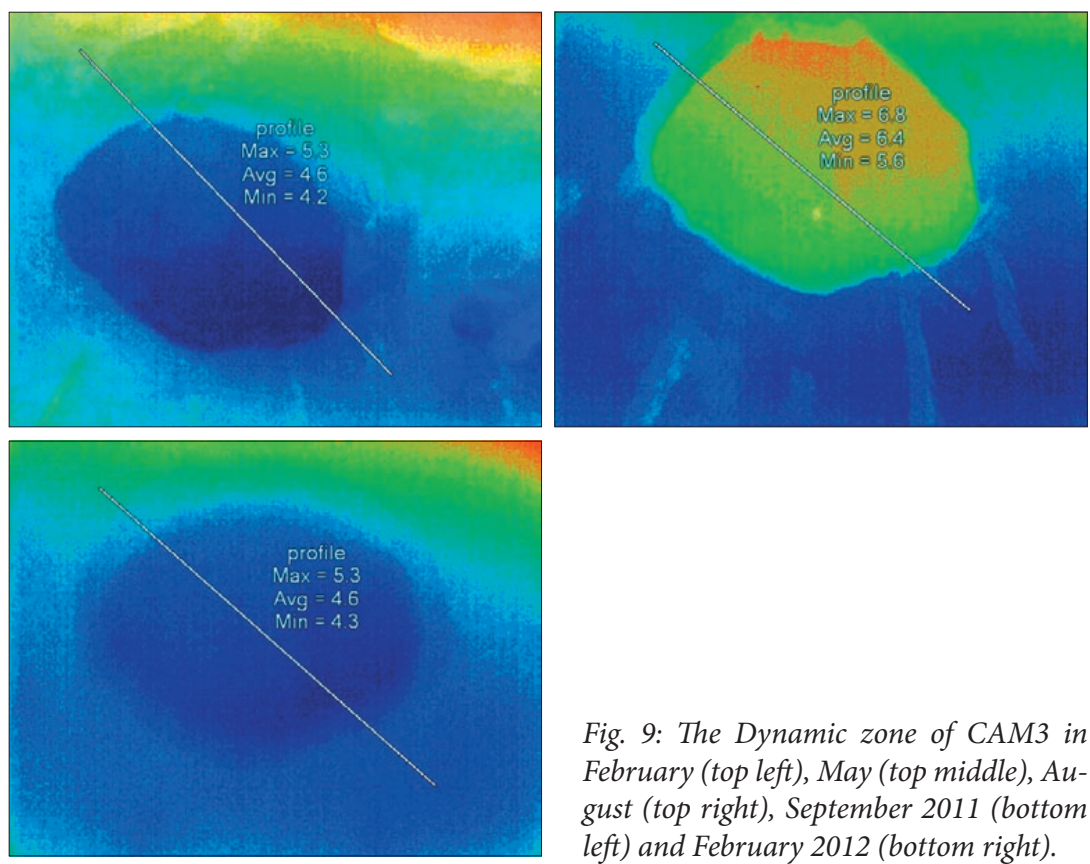

Fig. 9: The Dynamic zone of CAM3 in February (top left), May (top middle), August (top right), September 2011 (bottom left) and February 2012 (bottom right). 


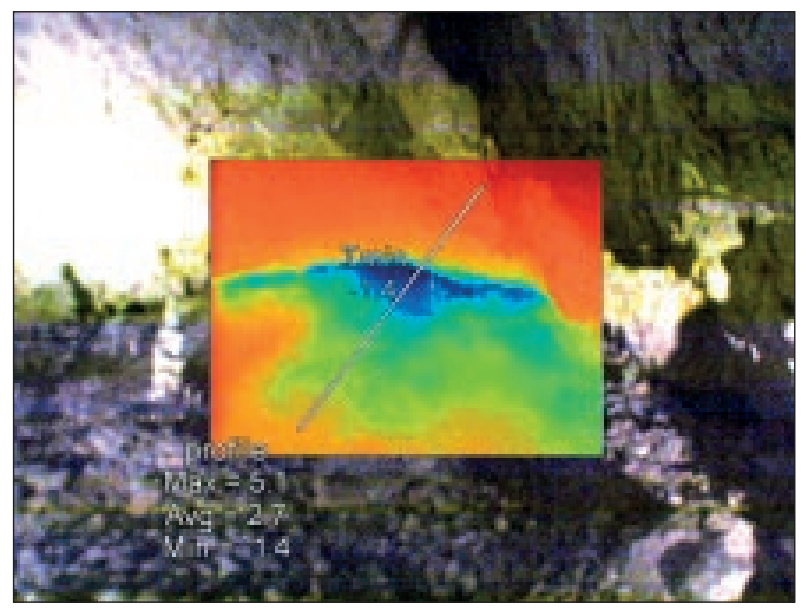

Fig. 10: Thermal recording of CAM6 dynamic zone in February 2012 - thermal image integrated into a visible image.

above the floor of the cave entrance corridor is colder than the rock under the ceiling and therefore absorbs more heat and energy from the relative warm air. The RST at ground level is significantly cooler than the air and the rock near the ceiling. Cold air entering from the entrance corridor greatly affects the temperature regime across the southern part of "Hlavní dóm" hall (see measurement by IR thermometer).

The morphology of "Suchý žleb" gorge and the thickness of overburden significantly reduces the effect of solar radiation on the cave interior. The active surface above the cave consists of mixed forest and therefore the insolation is significantly reduced. The exception is a zone of CAM3. The CAM3 area (Fig. 9) has a seasonal variability of maximum and temperature of $3.8^{\circ} \mathrm{C}$ and $3.5^{\circ} \mathrm{C}$ respectively (Tab. 2) due to heat conduction from the surface which is beeing insolated. Furthermore, pres-

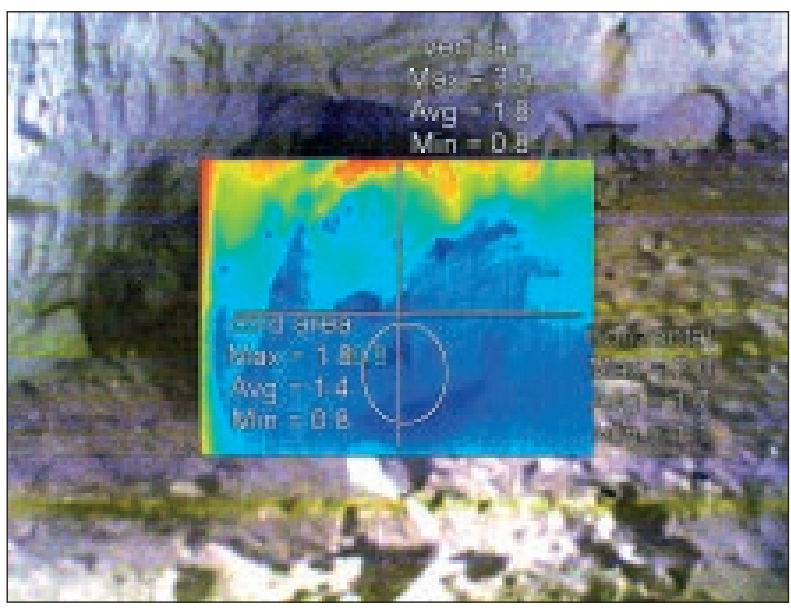

Fig. 11: Example of CAM4 dynamic zone detection in February 2012 - thermal image integrated into a visible image.

ence of tree roots in this part of the cave indicates thinner overburden layer and contact with the nearby cave environment.

The effect of the debris cone on the external environment by the debris cone in the area of "Kalvárie" and above "Bambusový lesík" (CAM6) was demonstrated by using a thermal IR camera for monitoring - Fig. 10. In this area, the seasonal variability of minimum surface temperature is up to $8.3^{\circ} \mathrm{C}$.

Temperature heterogeneous zones probably indicating unknown cave spaces and contacts with the exterior was also detected by point CAM4 (Fig. 11). For example, during a cold episode in February 2012, the RST was $3-4{ }^{\circ} \mathrm{C}$ lower than in the immediate vicinity (i.e., a few meters away) in this part of the cave. In this area, cold air also accumulates, which is demonstrated in Fig. 4.

\section{CONCLUSIONS}

The results are important for the karst formation research and are useful for efficient protection of the cave environment and biota. Proper management of accessible caves requires quantification of the external climate influence on it.

IR Sensors enable useful descriptions of the spatial and temporal temperature variability of the observed surfaces. With use of the planar information of an IR camera the approximate RST was obtained. An IR thermometer provides standard point outputs. A series of detailed IR thermometer points measuring along the entire length of the cave was transferred to the spatial output.
Interpolation methods enabled an expression of the RST as a daily step.

Through thermal imaging, heterogeneous zones in Kateřinská Cave in which we expect new and unknown spaces and/or communication with the exterior were located. Using IR camera monitoring, the effect of the exterior was clearly demonstrated in the "Kalvárie" above "Bambusový lesík" and apparently also in a small area in the southeast of "Hlavní dóm" hall. The effects of attenuated overburden and the effect of heat exchange by conduction were found in the blind corridor in the southern part of the "Hlavní dóm" hall. Significant influence of the 
exterior through the upper floors of the cave ("Dantovo peklo") across the chimney "Strojová chodba" (IS7) was not demonstrated. If the outside air flows to the "Dantovo peklo", it is most likely thermally transformed in vast areas and the climate of Katerinská Cave is not significantly affected.
The most dynamic part of the cave temperature is at the entrance corridor, which has several-fold higher dynamics than the rest of the cave. With increasing distance from the entrance, the temperature variability of the rock surface decreases, with the exception of those sites with a specific regime.

\section{ACKNOWLEDGEMENTS}

The work was supported by project ME No. SP/2D5/5/07

"Determination of cave microclimate depending on external weather conditions in CR show caves".

\section{REFERENCES}

Badino, G., 2010: Underground meteorology - „What's the weather underground?“.- Acta Carsologica, 39, 427-448.

Berenguer-Sempere, F., Gómez-Lende, M., Serrano, E. \& J.J. de Sanjosé-Blasco, 2014: Orthothermographies and 3D modeling as potential tools in ice cave studies: the Peña Castil Ice Cave (Picos de Europa, Northern Spain).- International Journal of Speleology, 43, 35-43.

Bourges, F., Genthon, P., Mangin, A. \& D. D'Hulst, 2006: Microclimates of L'Aven d'Orgnac and other French limestones caves (Chauvet, Esparros, Marsoulas).- International Journal of Climatology, 26, 1651-1670.

Boyles, J.G., Dunbar, M.B., Storm, J.J. \& V. Brack, 2007: Energy availability influences microclimate selection of hibernating bats.- The Journal of Experimental Biology, 210, 4345-4350.

Boyles, J.G., Storm, J.J. \& V. Brack, 2008: Thermal benefits of clustering during hibernation: a field test of competing hypotheses on Myotis sodalis.- Functional Ecology, 22, 632-636.

Calaforra, J.M., Fernández-Cortés, A., Sánchez-Martos, F., Gisbert, J. \& A. Pulido-Bosch, 2003: Environmental control for determining human impact and permanent visitor capacity in a potential show cave before tourist use.- Environmental Conservation, $30,160-167$.

Campbell, C.W., Abd, E.L.M. \& J.W. Foster, 1996: Application of thermography to karst hydrology.- Journal of Cave and Karst Studies, 58, 163-167.
Carrasco, F., Vadillo, I., Liñán, C., Andreo, B. \& J.J. Durán, 2002: Control of environmental parameters for management and conservation of Nerja Cave (Malaga, Spain).- Acta Carsologica, 31, 105-122.

Clawson, R.L., LaVal, R.K., LaVal, M.L. \& W. Caire, 1980: Clustering behavior of hibernating Myotis sodalis in Missouri.- Journal of Mammalogy, 61, 245-253.

Curtis, A. \& P. Kyle, 2011: Geothermal point sources identified in a fumarolic ice cave on Erebus volcano, Antarctica using fiber optic distributed temperature sensing.- Geophysical Research Letters, 38, 7 p.

De Freitas, C.R. \& R.N. Littlejohn, 1987: Cave climate: assessment of heat and moisture exchange.- Journal of Climatology, 7, 553-569.

De Freitas, C.R. \& A. Schmekal, 2005: Prediction of condensation in caves.- Speleogenesis and Evolution of Karst Aquifers, 3, 9 p.

Fernandez-Cortes, A., Sanchez-Moral, S., Cuezva, S., Cañaveras, J.C. \& R. Abella, 2009: Annual and transient signatures of gas exchange and transport in the Castañar de Ibor cave (Spain).- International Journal of Speleology, 38, 153-162.

Fluke , 2007: Fluke TiR2, TiR3, TiR4, Ti40, Ti45, Ti50, Ti55 IR FlexCam Thermal Imagers. Users manual. Rev. 2, 5/09.- Fluke Corporation, pp. 132, Everett, WA, USA.

Gabrovšek, F., Knez, M., Kogovšek, J., Mihevc, A., Mulec, J., Perne, M., Petrič, M., Pipan, T., Prelovšek, M., Slabe, T., Šebela, S. \& N. Ravbar, 2011: Development challenges in karst regions: Sustainable land use planning in the karst of Slovenia.- Carbonates and Evaporites, 26, 365-380. 
Hebelka, J., Piasecki, J. \& T. Sawiński, 2007: Air exchange in the Kateřinská Cave. First contribution.- Aragonit, 12, 136.

Hebelka, J., Korzystka, M., Piasecki, J., Sawiński, T., Rožnovský, J., Středová, H., Fukalová, P., Středa, T., Lejska, S. \& T. Litschmann, 2012: Stanovení závislosti jeskynního mikroklimatu na vnějších podmínkách ve zpřístupnèných jeskyních České republiky [in Czech].- Acta Speleologica, 3, 243 pp.

Jeannin, P.Y., 1991: Températures dans la zone vadose du karst.- In: Actes du 9e Congrès national de la SSS, Société Suisse de Spéléologie, 71-76, Charmey.

Luetscher, M. \& P.Y. Jeannin, 2004: Temperature distribution in karst systems: the role of air and water fluxes.- Terra Nova, 16, 344-350.

Luetscher, M., Lismonde, B. \& P.Y. Jeannin, 2008: Heat exchanges in the heterothermic zone of a karst system: Monlesi Cave, Swiss Jura Mountains.- Journal of Geophysical Research, 113, 13 p.

Lundberg, J. \& D.A. McFarlane, 2009: Bats and bell holes: The microclimatic impact of bat roosting, using a case study from Runaway Bay Caves, Jamaica.Geomorphology, 106, 78-85.

Martin, K.W., Leslie, D.M., Patron, M.E., Puckette, W.L. \& S.L. Hensley, 2006: Impacts of passage manipulation on cave climate: Conservation Implications for Cave-Dwelling Bats.- Wildlife Society Bulletin, 34, 137-143.

Milanolo, S. \& F. Gabrovšek, 2009: Analysis of carbon dioxide variations in the atmosphere of Srednja Bijambarska Cave, Bosnia and Herzegovina.- Boundary - Layer Meteorology, 131, 479-493.

Obleitner, F. \& C. Spötl, 2011: The mass and energy balance of ice within the Eisriesenwelt cave, Austria.The Cryosphere, 5, 245-257.

Piasecki, J. \& T. Sawiński, 2007: Acoustic measurements of airflow in speleo-climatological studies.- Karst and Cryokarst, Studies of the Faculty of Earth Science, University of Silesia, Sosnowiec - Wrocław, 45, 237-256.

Pflitsch, A., Grebe, Ch. \& M. Grudzielanek, 2012: About the use of thermal imaging in cave micrometeorological studies.- In: Akten des 13. Nationalen Kongresses für Höhlenforschung, 29 ${ }^{\text {th }}$ September- $1^{\text {st }}$ October 2012, Muotathal, Schweiz: Schweizerische Gesellschaft für Höhlenforschung. Kommission für Wissenschaftliche Speläologie, Arbeitsgemeinschaft für Speläologie Regensdorf, Arbeitsgemeinschaft Höllochforschung, Höhlengruppe Muotathal, 141144, Muotathal.
Raytek $^{\circledast}$, 1999: Raynger ${ }^{\circledast} M 4^{\mathrm{TM}}$ High performance infrared thermometer. Rev. D, 01/1999.- Raytek Corporation, pp. 111, Santa Cruz, California, USA.

Rinker, J.N., 1975: Airborne infrared thermal detection of caves and crevasses.- Photogrammetric Engineering and Remote Sensing, 41, 1391-1400.

Rožnovský, J., Středa, T., Litschmann, T., Pokladníková, H. \& P. Fukalová, 2010a: Mesoclimate as a part of recreation potential of the landscape on the example of the Moravian Karst.- In: Recreation and Environmental Protection, $5^{\text {th }}-6^{\text {th }}$ May 2010, Krtiny, Mendel University in Brno, 60-64, Brno.

Rožnovský, J., Fukalová, P., Pokladníková, H. \& T. Středa, 2010b: The impact of visitors on microclimate of Katerinska cave assessed on the base of ambulatory measurement in 2008 and 2009.- In: Recreation and Environmental Protection, $5^{\text {th }}-6^{\text {th }}$ May 2010, Krtiny, Mendel University in Brno, 167-171, Brno.

Smithson, P.A., 1993: Vertical temperature structure in a cave environment.- Geoarcheology, 3, 229-240.

Sun-Sook, K., Yu-Seong, Ch., Bong-Hyeon, K. \& Y. Neony-Chil, 2009: The current distribution and habitat preferences of hibernating Myotis formosus in Korea.- Journal of Ecology and Field Biology, 32, 191-195.

Šebela, S. \& J. Turk, 2011: Local characteristics of Postojna Cave climate, air temperature, and pressure monitoring.- Theoretical and Applied Climatology, $105,371-386$.

Thompson, J. \& M. Marvin, 2005: Experimental research using Thermography to locate heat signatures from caves.- In: Congress proceedings $14^{\text {th }}$ International Congress of Speleology, $21^{\text {st }}-28^{\text {th }}$ August 2005, 7074, Kalamos, Greece.

Turri, S., Citterio, M., Bini, A., Maggi, V., Favaron, M., Fraternali, D., Alberici, A., Borghi, S., Colombo, M., Gottardi, R. \& D. Zappalà, 2005: Preliminary data recorded by a monitoring station to study the hypogean climate in a ice cave: the LO LC 1650 Ice Cave "Abisso sul margine dell'Alto Bregai" (Grigna Settentrionale, Lecco - Italy).- In: Congress proceedings $14^{\text {th }}$ International Congress of Speleology, 21 $1^{\text {st }}-28^{\text {th }}$ August 2005, 74-79, Kalamos, Greece.

Wynne, J.J., Titus, T.N. \& G.Ch. Diaz, 2008: On developing thermal cave detection techniques for Earth, the Moon and Mars.- Earth and Planetary Science Letters, 272, 240-250.

Zelinka, J., 2002: Microclimatic research in the Slovakian show caves.- Acta Carsologica, 31, 151-163. 